\title{
Welfare Implications of Foreign Aid in Nigeria
}

\author{
Ovikuomagbe Oyedele ${ }^{1}$ and Esther Lawal ${ }^{2}$ \\ ${ }^{1}$ University of Ibadan, Ibadan, Nigeria PhD Economics Student Under the African Economic Research \\ Consortium(AERC) Collaborative PhD Program. \\ ${ }^{2}$ Department of Economics, Banking and Finance, Babcock Business School, Babcock University, Ilishan, Ogun \\ State, Nigeria.
}

\begin{abstract}
This paper examines the effect of foreign aid on welfare levels in Nigeria for the period 1971 to 2010. In order to capture the broad meaning of welfare as discussed in the theoretical framework, life expectancy at birth and household final consumption expenditure per capita are used as proxies for welfare. Employing a cointegration test and an error correction model, the study analyzes the effect of official development assistance plus official aid and total bilateral aid on life expectancy at birth. The results show that official development assistance plus aid and total bilateral aid have no significant effect on life expectancy at birth in the long run and short run. Household final consumption expenditure per capita is not significantly explained by official development assistance plus official aid and total bilateral aid when foreign direct investment is included in the model. However, when foreign direct investment is excluded from the model, total bilateral aid becomes negatively significant. The study concludes that factors responsible for the insignificance and negative impact of foreign aid in the results could include the lack of democracy, political and selfish interests of foreign aid negotiators, corruption and misappropriation in favour of wealthy elites and not the poor.
\end{abstract}

Keywords: Welfare, Foreign Aid, Life expectancy at Birth, Household Final Consumption Expenditure Per Capita

\section{Introduction}

Nigeria has consistently received official development assistance plus official aid since 1971 up to the tune of about $\$ 573 \mathrm{~m}$ in 1971 , about $\$ 79 \mathrm{~m}$ in 1980 , above $\$ 380 \mathrm{~m}$ in 1990 , above $\$ 12 \mathrm{~b}$ in 2006 and about $\$ 2 \mathrm{~b}$ in 2010. Total bilateral aid was about $\$ 90 \mathrm{~m}$ in $1971, \$ 18 \mathrm{~m}$ in 1980 , about $\$ 204 \mathrm{~m}$ in $1990, \$ 76 \mathrm{~m}$ in 2000 and $\$ 909.5 \mathrm{~m}$ in 2010 . Thus, we can say that foreign aid has been a major source of income for the country. Despite the consistent increase in foreign aid received, life expectancy at birth from 1971 to 2010 has ranged from 42.8 to 51.4, showing a poor health status of the population and a low security level for lives. Thus, only very few grow into old age. Household final consumption expenditure rose from a $\$ 7 \mathrm{~b}$ in 1971 to $\$ 55 \mathrm{~b}$ in 1985 and declined to $\$ 29 \mathrm{~b}$ in 1986 and $\$ 24 \mathrm{~b}$ in 2000 . It began to rise in 2001 to $\$ 33 \mathrm{~b}$ and maintained an increase to $\$ 152 \mathrm{~b}$ in 2010. Several works have investigated the effect of foreign aid and assistance on economies especially with respect to the GDP growth, investment levels and poverty reduction and have inferred some indirect effects on welfare (Masud and Yontcheva (2005), Svensson 2000, Svensson 1999). Few studies have examined the direct impact of foreign aid on the welfare of individuals (Arellano et al. 2009, Boone 1996 and Okon 2012). Most donors claim that the motive behind these aids is to improve the wellbeing of the entire citizens by enhancing development achievements. It is therefore pertinent to examine if the foreign aid received have actually had any effect on the wellbeing of the masses and whether this effect is positive. This could be achieved by assessing the welfare impacts with a focus on health and standard of living. This study therefore investigates the final effect of foreign aid on the general wellbeing of citizens. It examines the welfare implications of foreign aid in Nigeria by looking at its impact on life expectancy at birth and on household final consumption expenditure per capita for the period 1971 to 2010.

\section{Literature Review}

Several studies have examined the relationship between foreign aid and the well-being of the recipient country's citizens. Masud and Yontcheva (2005) examined the impact of foreign aid on poverty reduction proxied by human development indicators (infant mortality rate and illiteracy rate).they used a panel data of more than 50 countries for the period 1990 to 2001. Their results show that nongovernmental aid reduces infant mortality more effectively than bilateral aid. Total bilateral aid was found to have no significant impact on infant mortality. Improved GDP per capita and female literacy rate was seen to reduce infant mortality. Employing a two stage least squares estimator for the illiteracy rate model to control for endogeneity, both nongovernmental aid per capita and total bilateral aid per capita had no significant impact on the illiteracy rate. The level of governance or the average poverty level in a country had no significant impact on illiteracy. 
However, the level of urbanization was negatively significant. As shown by Arellano et al. (2009) in an aid sensitivity analysis, permanent foreign aid flows mainly increases consumption and not investment, making it impossible for aid inflows to translate into sustained growth. Using a calibrated model analysis for about 66 aiddependent countries they find that aid volatility results in substantial welfare losses. However, if aid flows from donors were more stable, even reductions in aid would still maintain the same level of well-being for citizens of aid-receiving countries. Also, if aid is delivered in such a way as to insure fully against productivity shocks, donors could reduce aid without reducing the present level of welfare because volatility shocks would have benefits equivalent to 64 percent of total aid. The subject of foreign aid having little or no macroeconomic impact has called for concerns in the literature. One of such concerns is expressed by Svensson (2000) who examined the link between foreign aid and rent-seeking. Employing a game-theoretic rent-seeking model and using a sample of aid-recipient countries from the various continents, he finds that corruption and other types of rent seeking activities largely reduce the effectiveness of foreign aid as a result of reduced productive public spending. Svensson (1999) also finds that the long run impact of aid on growth is conditional on the degree of political and civil liberties in the recipient country. Thus higher levels of democracy enable a positive aid impact on growth. Brautigam (1992) explains that large foreign aid receipts are responsible for the lack of accountability and poor governance in Western Europe. This is because when foreign aids get larger than government revenue from other sources, there is less pressure on the government to be accountable since most elites would benefit from the implementation strategy of the aids. However, if government have to depend more on revenue from taxation and as such have to go through the rigors of getting the citizens to understand why taxes should increase, the pressure on the government to be accountable to the citizens and provide the right amount of social services and infrastructure to improve welfare would be higher. Also, when foreign aid is low, government is forced to seek revenue from other sources such as the private sector by providing the enabling environment for foreign and domestic investors. This increase in investment has positive effects on welfare. According to Loayza et al. (2007), macroeconomic volatility entails welfare cost for risk-averse individuals and an indirect cost through an adverse impact on income, growth and development. In low-income countries, external shocks including foreign aid, terms of trade, international finance amongst others contributes a significant though small portion of overall macroeconomic volatility Raddatz (2007). Eregha and Irugbe (2009) examined the impact of foreign aid inflow on domestic savings in Nigeria. Using the Ordinary Least Squares estimation with an autoregressive model to examine short run and long run elasticity impacts, their results showed foreign aid inflow has a positive effect on domestic savings both in the short run and steady state.

\section{Theoretical Framework}

Pigou (1932) proposed a relationship between economic welfare and national income because both of them are measured in terms of money. He explains that when national income increases, total welfare also increases such that the effect of national income on welfare is explained in two ways- by changes in the size of national income and by changes in the distribution of national income. An increase in the size of national income would increase the amount of goods and services individuals are able to consume, thus increasing their economic welfare. However, this positive relationship depends on a number of factors. To begin, it is only an increase in national income caused by an increase in output and not prices that would improve welfare. Also, if labour is overworked to increase output but yet underpaid, national income may increase but labour is left in a poor economic state. In addition, if population increases at the same pace or faster than national income, per capita income declines and so does economic welfare. Finally, if the increase in consumption as a result of an increase in national income is geared towards unhealthy goods (alcohol and gambling), the health status of people will decline and so will their economic welfare.

A change in the distribution of national income that transfers wealth from the poor to the rich instead of vice versa would reduce economic welfare drastically.

There has been attempts to show that the national income is not a satisfactory measure for economic welfare because it does not include certain factors that affect human welfare. For instance, the quality of life of an individual reflects the individuals' welfare. Overcrowded cities, lack of good roads, frequent accidents, and the lack of infrastructures such as water, power supply, housing and transportation reduce the quality of life of individuals and cause a decline in social welfare. The quality of life however is not an item included in the calculation of the gross national product (GNP). The standard of living of individuals is not reflected in the national income estimate because if more national income is spent on procuring arms and ammunitions and less is spent on the production of consumption goods, this difference is not reflected in the GNP estimate despite the fact that the reduction in consumption goods reduces economic welfare. A few economists have therefore tried to broaden the definition of the GNP to adequately measure economic welfare. One of such attempt was made by Nordhaus and Tobin (1972). They introduced a measure of welfare called 'Net Economic Welfare' by deducting from consumption certain items that do not contribute to welfare and adding other items that contribute to welfare but are not included in the GNP estimate. Three deductions made include public and 
private expenditures that do not yield utility directly such as national defence, road maintenance; consumer expenditures on durable household goods which yield utility over their lifetime such as cars, washing machine; and costs arising from negative externalities of congestion and pollution. The three additions made to consumption include- the value of non-market activities; estimates of the value of the services of durable consumer goods used by households and government; and an estimated value of leisure.

From the discussions above, we can summarize that welfare has a wholistic meaning and captures amongst others, an individuals' standard of living (income and consumption), quality of life (health and leisure) and access to basic services and amenities including education and sanitation.

\subsection{Data and Source}

\section{Methodology}

The data used in this study include life expectancy at birth and household final consumption expenditure per capita (both are used as proxies for welfare), official development assistance and foreign aid, total bilateral aid, external debt total, foreign direct investment and electricity consumption per capita. All data are from the World Bank World Development Indicators 2012 except the household final consumption expenditure per capita gotten from kushnirs.org/macroeconomics/household consumption. All data cover the period 1971 to 2010 .

\subsection{Model specification}

In order to have a broader capture of welfare, this study follows Boone (1996) and Masud and Yontcheva (2005) by using social indicators and macroeconomic variables because most foreign aids target the achievement of Millennium development goals. The study will examine the impact of foreign aid on welfare (using three indicators- household final consumption expenditure and life expectancy at birth). An increase in a household's final consumption expenditure shows an increase in its economic welfare as the household has been able to consume more goods and services to improve its utility level. An improved quality of life is shown by the health and average longevity of a population as reflected by the life expectancy at birth. Access to basic services such as education, improve the capacity of individuals to create wealth. Three types of foreign aid are considered in this study- official development assistance plus official aid and total bilateral aid.

\section{Model I}

$\mathrm{LEB}=\mathrm{f}(\mathrm{OAD}, \mathrm{TBA}, \mathrm{EXD}, \mathrm{FDI}, \mathrm{ECPC})$

In its functional form,

$\mathrm{LEB}=\beta_{1}+\beta_{2} \mathrm{OAD}+\beta_{3} \mathrm{TBA}+\beta_{4} \mathrm{EXD}+\beta_{5} \mathrm{FDI}+\beta_{6} \mathrm{ECPC}+\varepsilon$

Where,

$$
\beta_{2}>0, \beta_{3}>0, \beta_{4}<0, \beta_{5}>0, \beta_{6}>0
$$

LEB $=$ life expectancy at birth.

$\mathrm{OAD}=$ official development assistance plus official aid

$\mathrm{TBA}=$ total bilateral aid

$\mathrm{EXD}=$ total external debt

$\mathrm{FDI}=$ foreign direct investment

$\mathrm{ECPC}=$ electricity consumption per capita

\section{Model II}

$\mathrm{HFCE}=\mathrm{f}(\mathrm{OAD}, \mathrm{TBA}, \mathrm{EXD}, \mathrm{FDI}, \mathrm{ECPC})$

In its functional form,

$\mathrm{HFCE}=\beta_{1}+\beta_{2} \mathrm{OAD}+\beta_{3} \mathrm{TBA}+\beta_{4} \mathrm{EXD}+\beta_{5} \mathrm{FDI}+\beta_{6} \mathrm{ECPC}+\varepsilon$ $\beta_{2}>0, \beta_{3}>0, \beta_{4}<0, \beta_{5}>0, \beta_{6}>0$

Where HFCE refers to the growth rate of household final consumption expenditure per capita

\subsection{Descriptive Statistics of Data}

\section{Data Analysis And Discussion}

As shown in Table 1 below, the mean household final consumption expenditure per capita is 110.6 with a maximum of 150 and a minimum of 52.7. The mean life expectancy at birth is 46 years with a maximum of 51 years. This shows a low longevity rate. Official development assistance plus official aid has a mean of about $\$ 8 \mathrm{~m}$ with a maximum of $\$ 125 \mathrm{~m}$ for the period 1971 to 2010 . The mean total bilateral aid is about $\$ 6 \mathrm{~m}$ with a maximum of $\$ 110 \mathrm{~m}$. The mean total external debt is about $\$ 191 \mathrm{~m}$ while foreign direct investment and electricity consumption per capita has a mean of about $\$ 16 \mathrm{~m}$ and 78 kilowatts per hour respectively. 
Table 1 Descriptive Statistics of Data

\begin{tabular}{|c|c|c|c|c|c|c|c|}
\hline Variables & HFCE & LEB & OAD & TBA & EXD & FDI & ECPC \\
\hline Mean & 110.565 & 46.1775 & 8913890 & 6031705 & $1.91 \mathrm{E}+08$ & 16464292 & 78.085 \\
\hline Median & 114.1 & 45.65 & 2814600 & 720700 & $2.04 \mathrm{E}+08$ & 8045073 & 80.15 \\
\hline Maximum & 150 & 51.4 & $1.25 \mathrm{E}+08$ & $1.10 \mathrm{E}+08$ & $3.78 \mathrm{E}+08$ & 85548408 & 138.3 \\
\hline Minimum & 52.7 & 42.8 & 665600 & 107800 & 9603630 & -7388700 & 0 \\
\hline Std Dev. & 20.79162 & 2.047073 & 22125231 & 19434206 & $1.26 \mathrm{E}+08$ & 22024419 & 30.12549 \\
\hline Skewness & -0.61736 & 1.045494 & 4.323248 & 4.504306 & -0.149338 & 1.937599 & -0.26692 \\
\hline Kurtosis & 3.533676 & 3.510661 & 21.6617 & 22.94462 & 1.406025 & 5.787735 & 3.003298 \\
\hline Observations & 40 & 40 & 40 & 40 & 40 & 40 & 40 \\
\hline
\end{tabular}

\subsection{Stationarity Test}

Employing the unit root test using the Augmented Dickey-Fuller test the results as shown in Table 2 reveal that household final consumption expenditure per capita and official development assistance and official aid are stationary at levels at the $1 \%$ and $5 \%$ levels of significance respectively. Foreign direct investment and electricity consumption per capita are stationary at first difference at the $1 \%$ and $5 \%$ significance levels respectively. Total bilateral aid, external debt total and life expectancy at birth are stationary at second difference at the $1 \%, 1 \%$ and $10 \%$ significance levels respectively.

Table 2 Stationarity Test Results

\begin{tabular}{|c|c|c|c|c|}
\hline Variables & Levels & First difference & $\begin{array}{l}\text { Second } \\
\text { difference }\end{array}$ & $\begin{array}{l}\text { Order of } \\
\text { Integration }\end{array}$ \\
\hline HFCE & $-5.273 *$ & Nil & Nil & $\mathrm{I}(0)$ \\
\hline LEB & Nil & Nil & $-2.855 * * *$ & $\mathrm{I}(2)$ \\
\hline OAD & $-3.402 * *$ & Nil & Nil & $\mathrm{I}(0)$ \\
\hline TBA & Nil & Nil & $-9.82 *$ & $\mathrm{I}(2)$ \\
\hline EXD & Nil & Nil & $-8.838^{*}$ & $\mathrm{I}(2)$ \\
\hline FDI & Nil & $-6.41 *$ & Nil & $\mathrm{I}(1)$ \\
\hline ECPC & Nil & $-3.501 * *$ & Nil & $\mathrm{I}(1)$ \\
\hline
\end{tabular}

$*$, $* *$ and $* * *$ represent $1 \%, 5 \%$ and $10 \%$ significance levels

Estimating the effect of foreign aid on welfare, we analyze two models. In the first model, welfare is proxied by life expectancy at birth and the second model uses household final consumption expenditure per capita as a welfare proxy.

\section{Model I}

This model consists of non-stationary variables and is given as:

$\mathrm{LEB}=\beta_{1}+\beta_{2} \mathrm{TBA}+\beta_{3} \mathrm{EXD}+\beta_{4} \mathrm{FDI}+\beta_{5} \mathrm{ECPC}+\varepsilon$

There is therefore the need for a cointegration test to ascertain the existence of a long run stable equilibrium relationship.

\subsection{Cointegration Test}

The Johansen cointegration test conducted show that there exists a long run equilibrium relationship among the non-stationary variables. The trace statistic shows that there are three cointegrating equations among the non-stationary variables. The maximum Eigen values however show that there are two cointegrating equations among the non-stationary variables. Both statistics are significant at 5 per cent.

\subsection{The Long Run Model}

The long run estimates of the life expectancy model are shown in Table 3 below. Total bilateral aid has a positive but insignificant effect on life expectancy at birth. These aids must have been offered for political rather than development reasons. Corruption factors could also have played a key role. Total external debt has a positive significant effect on welfare at the $10 \%$ significance level. This is probably due to the fact that in the long run, it is possible to spread the debt repayment effect overtime and enjoy some returns or gains from the project for which the debt was taken. Foreign direct investment has a positive effect on life expectancy at birth and it is significant at the $1 \%$ significance level. Electricity consumption per capita has a positive but insignificant effect in the long run. The overall model is highly significant from the F-statistics and the model's explanatory power is high. 


\subsection{Error Correction Model}

Following the cointegrating relationship, an error correction model is estimated to examine the short run adjustments. The results in Table3 have been corrected for heteroskedasticity by estimating using standard errors. Total bilateral aid has a negative effect on life expectancy at birth although it is not significant. Hence, these aids have not been directed towards improving the health and security of citizens. As shown by Boone (1996), aids received by the government could be diverted for the benefit of the rich who have relationships with those in power. Total external debt has a negative effect on life expectancy at birth such that as the level of external debt rises, more is spent on debt servicing than on providing goods and services that would improve the population's health. Foreign direct investment has a negative significant effect at the $5 \%$ level. Thus an increase in foreign direct investment flows reduces welfare. Thus, it has not directly improved the level of skilled manpower but has exploited labour in the areas of wages, salaries and work benefits. Electricity consumption per capita used as a measure for infrastructure availability has a positive effect on welfare measured by life expectancy at birth. The greater the available electricity consumed by each citizen, the higher the possibility for such individual to achieve his or her potentials conveniently. The error correction term has a negative coefficient of -0.01 indicating that for any disequilibrium in the short run, an adjustment to the tune of 0.01 is required to bring the life expectancy at birth model back to equilibrium. The regressors are jointly statistically insignificant. Hence in the short run, they do not adequately explain changes in welfare levels.

Table 3 Regressions for Model I (Long Run Model (LRM) and Error Correction Model (ECM)

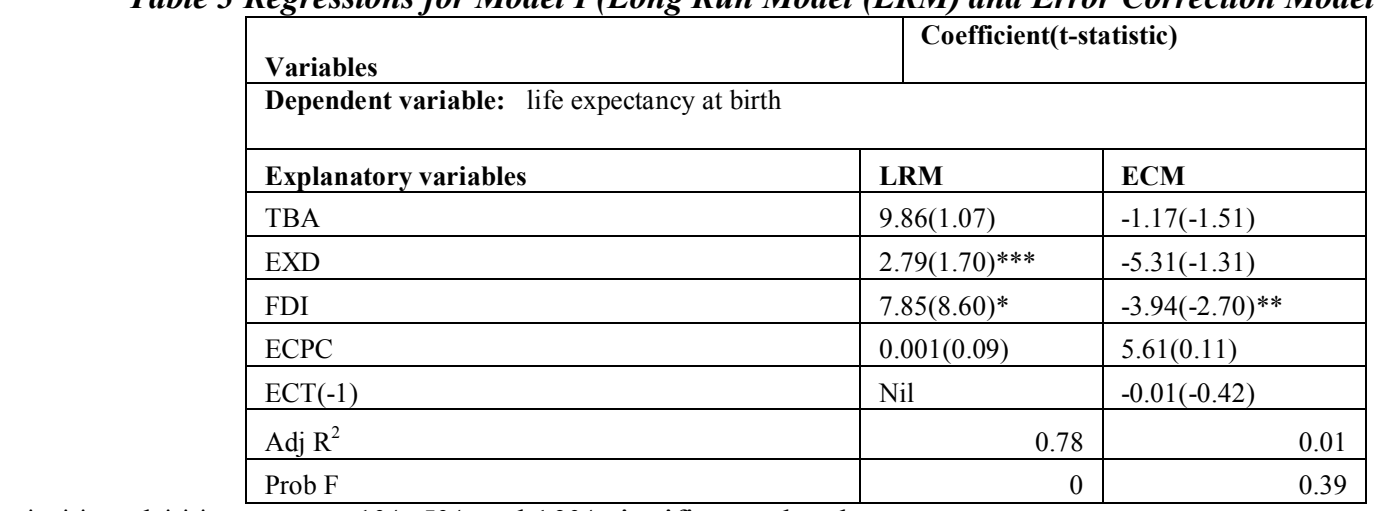

$*, * *$ and $* * *$ represent $1 \%, 5 \%$ and $10 \%$ significance levels

\section{Model II}

Household final consumption expenditure per capita is stationary at levels so we proceed to estimate the model, correcting for heteroskedasticity using standard errors. The results are presented in Table 4 below. In regression I, all regressors are included in the estimation. Official development assistance plus official aid has a positive effect on household final consumption expenditure per capita. Total bilateral aid has a negative effect on welfare measured by household final consumption expenditure per capita. Total external debt and foreign direct investment has a negative effect while electricity consumption per capita has a positive effect. Overall, none of the variables is significant showing that welfare changes during the period is not explained by the level of foreign aid nor other variables in the model. With an insignificant F-statistic, the model is however weak in explaining changes in household final consumption expenditure. In regression II, foreign direct investment is excluded from the model. In this case, only total bilateral aid becomes significant at the $10 \%$ significance level with a negative effect; although the joint explanatory power of the model is still weak.

Table 4 Regression Estimates of Model II

\begin{tabular}{|c|c|c|}
\hline \multicolumn{3}{|c|}{ 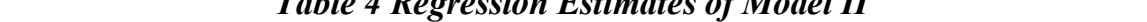 } \\
\hline \multirow{2}{*}{\multicolumn{3}{|c|}{\begin{tabular}{l|l} 
Variables & \\
Dependent variable: Household final consumption expenditure per capita
\end{tabular}}} \\
\hline & & \\
\hline Explanatory variables & Regression 1 & Regression 2 \\
\hline OAD & $7.16(0.53)$ & $4.12(0.40)$ \\
\hline TBA & $-2.14(-1.40)$ & $-2.33(-1.93)^{* * *}$ \\
\hline EXD & $-7.89(-0.97)$ & $-7.33(-1.02)$ \\
\hline FDI & $-2.76(-0.55)$ & Nil \\
\hline ECPC & $0.01(0.08)$ & $-0.05(-0.51)$ \\
\hline $\operatorname{Adj} R^{2}$ & -0.07 & -0.04 \\
\hline Prob F & 0.74 & 0.66 \\
\hline
\end{tabular}

$*, * *$ and $* * *$ represent $1 \%, 5 \%$ and $10 \%$ significance levels 


\section{Summary And Concluding Remarks}

Official development assistance plus official aid does not have a significant impact on life expectancy at birth and household final consumption expenditure per capita. Total bilateral aid significantly affects household final consumption expenditure per capita only when foreign direct investment is excluded from the model. Its effect however is negative. Thus, even when foreign aid is significant, it reduces welfare. This could be explained by the high level of corruption and misappropriation of funds by the government and private bodies who are transition agents for aids. Also, political and selfish interests of foreign aid negotiators could explain why foreign aid has no impact on welfare. For instance, conditional loans may not always be to the benefit of recipient countries. As shown by Svensson (1999), political instability and lack of democracy are possible reasons for negative effects.

\section{References}

[1]. Arellano, C., A. Bulir, T. Lane and L. Lipschitz 2009 "The Dynamic Implications of Foreign Aid and its Variability" Journal of Development Economics 88, pp. 87-102

[2]. Brautigam, D. 1992 "Governance, Economy and Foreign Aid" Studies in Comparative International Development 27(3), pp. 3-25

[3]. Boone, P. 1996 "Politics and the Effectiveness of Foreign Aid" European Economic Review 40, pp.289-329

[4]. Eregha, P. B. and I. R. Irugbe 2009 "An Empirical Analysis of the Short Run and Long Run Impacts of Foreign Aid on Domestic Savings in Nigeria" Journal of Economic Theory 3(3), pp. 53-56

[5]. Loayza, M. V., R. Ranciere, L. Serven, and J. Ventura 2007 "Macroeconomic Volattility and Welfare in Developing Countries: An Introduction" The World Bank Economic Review 21(3), pp. 343-357

[6]. Masud, N. and B. Yontcheva 2005 "Does Aid Reduce Poverty? Empirical Evidence from Nongovernmental and Bilateral Aid" International Monetary Fund Working Paper WP/05/100

[7]. Nordhaus, W. and J. Tobin 1972 "Is Growth Obsolete". In M. L. Jhinghan Macroeconomic Theory 1997 11th Edition Vrinda Publications (P) Ltd

[8]. Pigou, A. C. 1932 "The Economics of welfare" pp11

[9]. Raddatz, C. 2007 "Are external Shocks Responsible for the Instability of Output in Low-income Countries" Journal of Development Economics 84(1), pp.155-187

[10]. Svensson, J. 1999 "Aid, Growth and Democracy" Economics and Politics 11 (3), pp.275-297

[11]. Svensson, J. 2000 "Foreign Aid and Rent-Seeking" Journal of International Economics 51, pp.437-461 